ISSN : 2087-2461

PENANGGUNG JAWAB Dekan FIKOM

Evie Sofiati MI, M.I.Kom

Sekretaris Dekan

Dian Marhaeni K, M.Si

Ketua Penyunting

Made Dwi Adnjani, M.Si

Sekretaris

Mubarok, M.Si

Bendahara

Parwati, SH

Dewan Penyunting

Trimanah, M.Si

Edi Ismoyo, M.Si

Suharyoso, S.Sos

Seksi Usaha

Endang Winarsih, S.Sos

Sirkulasi dan Distribusi

Aldino Leoniv, ST

Alamat Redaksi

Fakultas Ilmu Komunikasi

Universitas Islam

Sultan Agung Semarang

J1. Raya Kaligawe Km. 4

Po. Box 1054/SM

Semarang 50112

Telp. (024) 6583584

ext. $448 / 449$

Fax. (024) 6582455

email : jurnalfikom@yahoo.com
Pengaruh Perubahan Nama Terhadap Citra Pada Telkom

University

Felesia Ekafaya Kirianawati, Roro Retno Wulan,

Kharisma Nasionalita

felesiaekafay@gmail.com

Komunikasi Lintas Budaya Etnis India, Etnis China serta

Pribumi di kampung Lubuk Pakam

Meilani Dhamayanti

mdhamayanti73@gmail.com

Analisis Komunikasi Pemasaran Melalui Strategi Brand Activation Pond's Untuk Meraih Top Brand Award 2013 Rustono Farady Marta ${ }^{1}$, Pricillia ${ }^{2}$, Maria Fransisca Kosasih ${ }^{3}$, Maria Christina Evelyn Iskandar ${ }^{4}$

rustonofarady@gmail.com ${ }^{1}$, icil_22@hotmail.com ${ }^{2}$, s43_s43@yahoo.com ${ }^{3}$,

mariachristinaevelyne@gmail.com ${ }^{4}$

Analisis Isi Visual Iklan Dan Strategi Kreatif Kategori Print Ad Pemenang Gold, Silver, dan Bronze Citra Pariwara 2015

Dina Nur Handayani ${ }^{1}$ (dinurhdyn@gmail.com)

Ratih Hasanah Sudrajat ${ }^{2}$ (kumaharatih@gmail.com ${ }^{2)}$

Ayub Ilfandy Imran ${ }^{3}$ (a_ilfandy@yahoo.com ${ }^{3}$ )

Refleksi Citra Indonesia Sebagai Dampak Politik Migrasi TKI

ke Malaysia

Mutia Rahmi Pratiwi (mutiarahmipratiwi@gmail.com)

Amida Yusriana (amidayusriana88@gmail.com)

$46-59$

Karakteristik Press Release Praktisi Public Relations Hotel di Yogyakarta

Margaretha Sonya, Meylani Yo, Nobertus Ribut Santoso

margaretha_sonyalee@yahoo.com

$60-70$

Isu LGBT dalam Bingkai Media Online

Muhammad Ghifari Putra ${ }^{1}{ }^{1}$ ghifarigp@gmail.com)

Kharisma Nasionalita ${ }^{2}$

${ }^{2}$ nasionalita.kharisma@gmail.com

$71-87$

Telepon Selular dan Ruang Publik : Representasi Identitas Siswantini

yjuliman@gmail.com

$88-94$

Kepemilikan dan Bingkai Media (Analisis Framing Pemberitaan Joko Widodo Sebagai Kandidat Calon Presiden pada Koran SINDO)

Nani Kurniasaril (nani.kurniasari@kalbis.ac.id ${ }^{1}$ )

Gilang GustiAji² (gilangaji@unesa.ac.id²)

$96-116$ 


\title{
PENGARUH PERUBAHAN NAMA TERHADAP CITRA PADA TELKOM UNIVERSITY
}

\author{
Oleh : \\ Felesia Ekafaya Kirianawati, Roro Retno Wulan, Kharisma Nasionalita \\ Jurusan Ilmu Komunikasi, Fakultas Komunikasi Bisnis, Universitas Telkom \\ felesiaekafay@gmail.com
}

\begin{abstract}
Telkom University is one of university in Bandung, was established on August 14, 2013. Telkom University was transformed of STT Telkom which standing on 1990. Based on observation which held by researcher, many people still consider that Telkom University still same with STT Telkom. But actually the case is Telkom University have different identity with STT Telkom. That's problem surely will be influence to image of Telkom University. This research have purpose to know how the relation name changes of STT Telkom being Telkom University about image of Telkom University to Bandung society. The theories used in this research are the public relation theory as a grand theory, rebranding theory as a middle theory, and then renaming theory and corporate image theory as an applied theory. This study is using the assosiatif methods, that is to find relation about independent variable and dependent variable. Using with survey methods to the 200 Bandung society as the respondents were selected using multistage of cluster sampling techniques. To determine the relation both of this variable in this research, used deskriptive techniques, pearson correlation techniques and also regression technique. The result showed that there are positive relation and significant between renaming of STT Telkom being Telkom University to image of Telkom University in Bandung Society.
\end{abstract}

\begin{abstract}
Abstrak
Telkom University adalah salah satu peruguruan tinggi swasta di Bandung, disahkan pada tanggal 14 Agustus 2013. Telkom University merupakan transformasi dari STT Telkom yang telah berdiri pada tahun 1990. Berdasarkan hasil observasi awal yang dilakukan peneliti, menunjukkan bahwa mayoritas masyarakat menganggap Telkom University masih sama sebagai STT Telkom. Padahal Telkom University dengan STT Telkom memiliki identitas yang berbeda. Hal ini tentu akan berpengaruh terhadap citra Telkom University. Penelitian ini dimaksudkan untuk mengetahui bagaimana pengaruh perubahan nama STT Telkom menjadi Telkom University terhadap citra Telkom University. Teori yang digunakan dalam penelitian ini adalah teori public relation sebagai grand theory, teori rebranding sebagai middle theory, kemudian teori renaming dan teori corporate image sebagai applied theory. Penelitian ini menggunakan metode assosiatif kausal yaitu untuk mengetahui pengaruh antara variabel bebas terhadap variabel terikat. Dilakukan survey kepada 200 masyarakat Kota Bandung yang terpilih menggunakan teknik multistage cluster sampling. Untuk mengetahui hubungan kedua variabel tersebut, menggunakan teknik deskriptif, korelasi pearson product moment dan regresi. Hasil penelitian menunjukkan bahwa terdapat hubungan dan pengaruh yang positif dan signifikan antara perubahan nama Telkom University terhadap citra Telkom University pada masyarakat Kota Bandung.
\end{abstract}

Kata kunci: renaming, brand name, corporate image 
Felesia Ekafaya Kirianawati, Roro Retno Wulan, Kharisma Nasionalita

\section{Pendahuluan}

Telkom University adalah salah satu perguruan tinggi swasta di Bandung, yang merupakan transformasi dari Sekolah Tinggi Teknologi Telkom atau sering disebut STT Telkom. STT Telkom berdiri pada tahun 1990, didirikan atas prakarsa PT. Telkom yang saat itu dipimpin oleh Direktur Utama Ir. Cacuk Sudarijanto. STT Telkom merupakan institusi pertama di Indonesia yang mengkhususkan program studinya pada bidang Information and Communications Technologies (ICT). Hal ini yang menyebabkan STT Telkom memiliki identitas kuat sebagai Perguruan Tinggi "enginering". Selain itu STT Telkom menggunakan nama besar sebuah perusahaan Telekomunikasi Indonesia Tbk (PT Telkom), yang merupakan perusahaan Badan Usaha Milik Negara (BUMN) di Indonesia, dan menerapkan Sekolah Kedinasan pada STT Telkom. Kini STT Telkom telah bertransformasi menjadi sebuah universitas. Sekolah Tinggi dengan Universitas memiliki definisi yang berbeda. Sekolah Tinggi adalah suatu lembaga pendidikan yang memberikan pengajaran tinggi serta melakukan penelitian dalam satu cabang ilmu pengetahuan, sedangkan Universitas adalah Perguruan Tinggi yang tersusun atas dasar keseluruhan, kesatuan ilmu pengetahuan dan terbagi atas sekurang-kurangnya empat golongan Fakultas meliputi Ilmu Agama, Ilmu Kebudayaan, Ilmu Sosial, Ilmu Eksakta dan Teknik. STT Telkom hanya menyediakan program studi di bidang Teknik maka dari itu STT Telkom memiliki identitas yang kuat sebagai Sekolah "enginering". Sedangkan Telkom University terdiri dari 7 fakultas mulai dari Fakultas Teknik, Manajemen, Ilmu Terapan, hingga Seni.

Masyarakat Indonesia sebagai publik eksternal Telkom University masih belum mengetahuinya dan hanya mengenal STT Telkom. Hal ini berdasarkan hasil pretest dan observasi yang dilakukan peneliti. Peneliti melakukan wawancara singkat terhadap 30 masyarakat Indonesia secara acak dengan mengajukan pertanyaan "Apakah anda mengetahui Telkom University? Kalau STT Telkom?". Dan berikut hasilnya:

\section{Gambar Pengetahuan Masyarakat Tentang} Telkom University

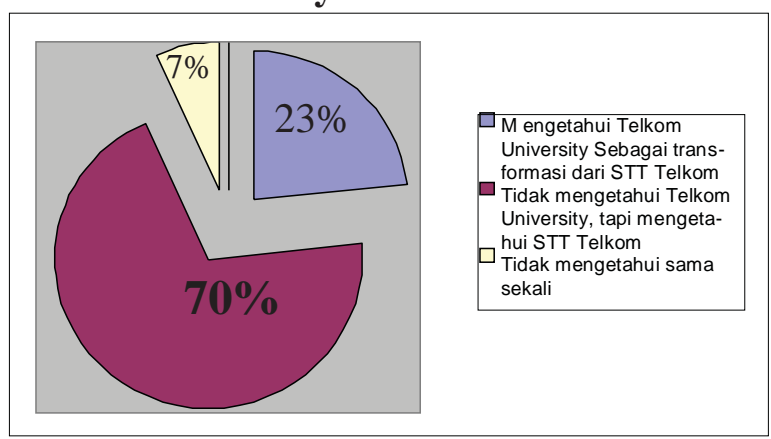

(Sumber: Olahan Peneliti Berdasarkan Hasil Pretest)

Berdasarkan hasil pretest tersebut, menunjukkan bahwa mayoritas masyarakat belum mengenal Telkom University, tetapi mereka mengetahui STT Telkom. Dan hanya 23\% yang mengetahui Telkom University sebagai Transformasi dari STT Telkom. Bahkan masih ada beberapa orang yang mengaku tidak mengetahui sama sekali mengenai Telkom University maupun STT Telkom. Selain itu peneliti juga melakukan observasi melalui search engine (google.co.id) untuk mengetahui apakah STT Telkom masih eksis sampai sekarang. Dan Berikut hasilnya:

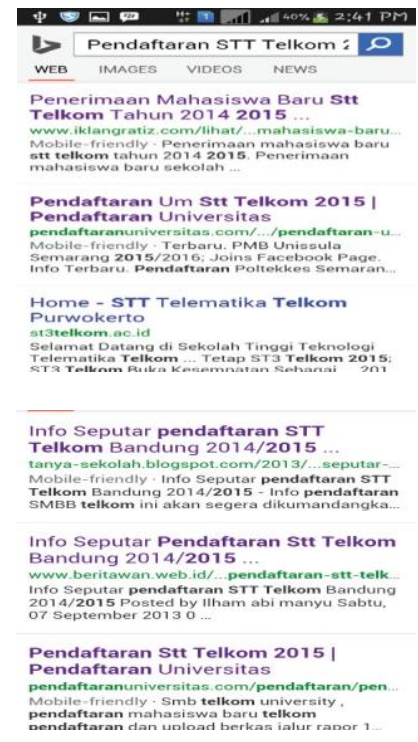

(Sumber: www.google.co.id)

Gambar 1.2 tersebut membuktikan bahwa STT Telkom masih eksis sampai sekarang. Meskipun STT Telkom sudah 
Felesia Ekafaya Kirianawati, Roro Retno Wulan, Kharisma Nasionalita

bertransformasi menjadi Telkom University. Kondisi inilah yang harus diperhatikan oleh Telkom University untuk menciptakan strategi branding yang kuat dan terus menerus agar dapat menggantikan identitas STT Telkom yang sudah berganti menjadi Telkom University pada publiknya.

Perguruan Tinggi harus menyadari bahwa identitas sebuah institusi merupakan suatu hal yang penting untuk diperhatikan. Identitas tersebut akan menciptakan citra yang akan diingat oleh publiknya. Selain itu, sebagai suatu Perguruan Tinggi, citra yang positif merupakan salah satu aspek penting agar dipilih calon mahasiswa.

Berdasarkan uraian di atas, peneliti tertarik untuk meneliti bagaimanakah pengaruh perubahan nama STT Telkom menjadi Telkom University, terhadap citra Telkom University. Dengan respondennya adalah masyarakat Kota Bandung yang merupakan salah satu target pemasaran Telkom University. Hal ini diperkuat berdasarkan data mahasiswa Telkom University yang menunjukkan bahwa mahasiswa Telkom University terbanyak berasal dari Kota Bandung.

\section{Public Relation}

Cutlip and Center (2009: 6) menjelaskan Public Relations merupakan fungsi manajemen yang membangun dan mempertahankan hubungan yang baik dan bermanfaat antara organisasi dengan publik yang mempengaruhi kesuksesan atau kegagalan organisasi tersebut. Sedangkan definisi menurut Frank Jefkins (2003), public relation adalah semua bentuk komunikasi yang terencana, baik itu kedalam maupun keluar, antara satu organisasi dengan semua khalayaknya dalam rangka mencapai tujuantujuan yang spesifik berlandaskan pada saling pengertian. Rosady Ruslan (2002: 30) menyatakan bahwa salah satu peran penting public relation adalah Good image maker, yaitu Menciptakan citra atau publikasi yang positif merupakan prestasi, reputasi dan sekaligus menjadi tujuan utama bagi
Pengaruh Perubahan Nama Terhadap Citra Pada Telkom University

aktivitas public relations dalam melaksanakan manajemen kehumasan membangun citra atau nama baik lembaga/organisasi dan produk yang diwakilinya.

\section{Rebranding}

Menurut Muzellec et al (2003), rebranding merupakan tindakan perusahaan di mana nama baru dipilih dan diadopsi untuk digunakan. Muzellec pun memberikan karakterisasi yang memungkinkan untuk rebranding adalah sebuah kreasi pembaruan dari nama, istilah, simbol, atau kombinasi dari mereka untuk menetapkan brand dengan tujuan untuk mengembangkan posisi baru yang berbeda di pikiran stakeholder dan kompetitor. Menurut Muzellec et al., (2006), terdapat empat elemen rebranding, yaitu repositioning, renaming, redesign dan relaunch. Pada penelitian ini, peneliti memfokuskan Rebranding hanya pada elemen Renaming, hal ini dikarenakan ditinjau dari latar belakang masalah yang ditemukan bahwa Telkom University merupakan nama baru dari Institusi yang ada sebelumnya.

Nama merek merupakan indikator utama dari sebuah merek, dasar dari kesadaran dan komunikasi. Renaming bukan hanya perubahan pada nama namun juga dapat terjadi pada slogan merek. Kapferer (1997) menyebutkan bahwa nama mendefinisi dan mewakilkan perusahaan atau identitas produk dan citranya.

Muzellec (2006) menjelaskan bahwa nama merek menjadi wajah atau indikator sebuah merek. Jika wajah berubah, maka isinya juga akan berubah. Perubahan nama merek mengisyaratkan berubahnya perusahaan baik dari strategi, kepemilikan, ataupun nilai dan posisi perusahaan.

\section{Renaming}

Shimp (2003: 299) juga menjelaskan bahwa, perubahan merek sangat penting untuk membedakan produk kita dengan produk pesaing. Muzellec et al. (2006) menyebutkan 
Felesia Ekafaya Kirianawati, Roro Retno Wulan, Kharisma Nasionalita

bahwa renaming penting karena nama merek memegang peranan penting karena menjadi wajah atau indikator awal sebuah merek. Nama merek yang kuat adalah aset yang mendemonstrasikan kekuatan entitas merek. Merubah nama merek berarti memberikan sinyal kepada stakeholder bahwa perusahaan melakukan perubahan, baik perubahan strategi, kepemilikan dan lainnya.

Idealnya, nama merek harus menangkap intisari dari merek dan dapat dimiliki dan digunakan di semua pasar, untuk mempermudah perlindungan merek dagang (Duane Knapp, 2004: 122). Melalui pertimbangan tersebut, karakteristik nama merek yang sesuai dengan penelitian ini adalah sebagai berikut:

a). Penerimaan, yaitu nama merek dapat diterima publik di mana merek tersebut akan dipasarkan.

b). Ketersediaan, yaitu nama merek dapat digunakan untuk suatu jenis tertentu dalam produk/jasa dengan melakukan pencarian merek dagang.

c). Keunikan, yaitu nama merek harus mudah terbedakan, harus spesifik dan khas.

d). Kredibilitas, yaitu nama merek harus mudah diucapkan, dikenal, diingat. Nama yang singkat akan sangat membantu.

e). Kesesuaian, yaitu nama merek harus menujukan bidang produk/jasa yang ditawarkan.

Kemudian kelima kriteria tersebut menggabungkan beberapa teori nama merek yang efektif menurut Knapp (2004), Rangkuti (2008) dan Muzellec (2003) yang kemudian peneliti melakukan elaborasi ketiga teori tersebut. Kelima kriteria itu akan menjadi indikator pada variabel renaming dalam penelitian ini.

\section{Corporate Image}

Definisi corporate image menurut Kotler (2009: 31) adalah Corporate image as the overall impression and organization has made on people's minds, the sum beliefs,
Pengaruh Perubahan Nama Terhadap Citra Pada Telkom University

attitudes, and impression that a person or group has an object. Berdasarkan pengertian tersebut, Kotler menjelaskan bahwa citra perusahaan merupakan keseluruhan kesan perusahaan yang ada dalam benak konsumen, seperti kepercayaan, perilaku dan kesan seseorang atau kelompok terhadap suatu objek.

Selanjutnya Smith (1995: 29) menguraikan bahwa citra perusahaan meliputi berbagai aktivitas perusahaan mulai dari kesan visual, logo, kop dokumen, stempel, poster dan proses keramahan pelayanan, tata letak kantor, pilihan warna dan corak seragam, karpet, walpaper, penyejuk ruangan, aroma kantor, desain interior hingga masalah yang langsung berkaitan dengan kualitas bisnis perusahaan baik barang maupun jasa. Dalam penelitian ini, peneliti ingin mengetahui citra yang terbentuk pada Telkom University setelah adanya perubahan nama baru yang diterapkan.

Adapun elemen-elemen citra menurut Keller (2008: 56), yaitu:

a). Strength (kekuatan)

Strengthness of brand association tergantung dari banyaknya jumlah atau kuantitas dan kualitas informasi yang diterima oleh konsumen. Semakin dalam konsumen menerima informasi merek, semakin kuat asosiasi merek yang dimilikinya. Dua faktor yang mempengaruhi strengthness of brand association yaitu hubungan personal dari informasi tersebut dan konsistensi informasi tersebut sepanjang waktu.

b). Favorability (kesukaan)

Favorability of brand association terbentuk oleh program pemasaran yang berjalan efektif mengantarkan produkproduknya menjadi produk yang disukai oleh konsumen.

c). Uniqueness (keunikan)

Dengan adanya asosiasi unik dari suatu merek, akan tercipta keuntungan kompetitif dan alasan-alasan mengapa konsumen sebaiknya membeli brand 
tersebut. Asosiasi unik dirancang agar konsumen "tidak ada alasan untuk tidak" memilih merek tersebut.

Sedangkan menurut Duncan (Alifahmi, 2012: 85) adapun tahapan dalam Branding yang dapat menciptakan sebuah brand image untuk menarik hati dan pikiran seorang konsumen, yaitu sebagai berikut :

\section{a). Brand Recognition}

Tahap pengenalan produk baru untuk menjadi produk yang familiar di mata publik. Faktor kegagalannya apabila produk tidak tersedia di pasaran.

b). Brand Preference

Tahap dimana konsumen telah memiliki pengalaman dengan suatu produk yang dipilih dan dirasa cukup memenuhi kebutuhan sehingga menjadi preferensi dari berbagai produk alternatif. Indikator keberhasilannya jika terdapat pengalaman yang baik terhadap suatu produk yang mencapai titik kepuasan.

\section{c). Brand Insistence}

Tahap dimana konsumen memutuskan untuk mengkonsumsi suatu produk terus menerus. Indikator kesuksesannya adalah apabila konsumen mengenal kelebihan produknya dibandingkan produk kompetitor dan merasa aman untuk mengkonsumsinya.

\section{d). Lovely Brand}

Tahap dimana konsumen benarbenar suka terhadap pengalaman yang dialami berulang-ulang dari penggunaan brand. Faktor pendukung tahap ini adalah ketika sebuah brand telah menjadi populer di pasaran.

Berdasarkan penjelasan tersebut, dapat diketahui bahwa suatu citra memiliki elemenelemen dan menggunakan tahapan branding dalam mencapai elemen tersebut. Maka dari itu, dalam penelitian ini peneliti menggunakan strenght, favorability dan uniqueness sebagai sub variabel dalam corporate image. Kemudian tahapan branding menurut Duncan tersebut menjadi indikatornya.

\section{Metodologi}

Paradigma dalam penelitian ini adalah positivistik dengan pendekatan kuantitatif. asosiatif dengan hubungan kausal, yaitu penelitian yang bertujuan untuk mengetahui hubungan antara dua variabel atau lebih dan yang memiliki hubungan sebab akibat. Objek penelitian pada penelitian ini adalah Telkom University dengan respondennya adalah masyarakat kota Bandung.

Populasi dalam penelitian ini adalah seluruh masyarakat Kota Bandung. Menurut data yang diperoleh dari Dinas Kependudukan Kota Bandung 2015, jumlah penduduk kota Bandung adalah 2.748 .733 orang. Jumlah tersebut sangat banyak untuk dilakukan penelitian, maka dari itu peneliti menggunakan Teknik Multistage Cluster untuk menarik sejumlah sampel.

Teknik Multistage Cluster Sampling yaitu populasi dibagi atas kelompok berdasarkan area atau cluster, kemudian beberapa cluster dipilih sebagai sampel (Siregar, 2013: 132). Dalam penelitian ini tahapan cluster dilakukan beberapa kali. Berdasarkan teknik tersebut, maka didapatkan jumlah responden dalam penelitian ini adalah 200 orang.

Dalam penelitian ini, pengolahan data kuesioner menggunakan teknik korelasi pearson dan regresi untuk mencari hubungan dan pengaruh antara variabel renaming dan corporate image.

\section{Hasil Pengujian}

Penelitian ini menggunakan teknik korelasi pearson product moment untuk mengetahui hubungan antara variabel bebas dan terikat. Hasil korelasi pearson yang akan menjelaskan hubungan renaming dengan corporate image dalam penelitian ini dapat dilihat dalam tabel berikut: 
Tabel Hasil Korelasi Pearson Product Moment

\begin{tabular}{|c|c|c|c|c|c|}
\hline & & Renaming & Strength Of Image & Favorability Of Image & Uniqueness Of Image \\
\hline \multirow{3}{*}{ Renaming } & Pearson Correlation & 1 & 451 , & 513, & ${ }^{*} 838$ \\
\hline & (Sig. (2-tailed & 000 & 000 & 000 & 000 \\
\hline & $\mathrm{N}$ & 200 & 200 & 200 & 200 \\
\hline \multirow{3}{*}{$\begin{array}{l}\text { Strength of } \\
\text { Image }\end{array}$} & Pearson Correlation & ${ }^{* * 4} 451$, & 1 & **354, & 413 \\
\hline & (Sig. (2-tailed & 000 & 000 & 000 & 000 \\
\hline & $\mathrm{N}$ & 200 & 200 & 200 & 200 \\
\hline \multirow{3}{*}{$\begin{array}{c}\text { Favorability } \\
\text { Of Image }\end{array}$} & Pearson Correlation & 513 & 670 & 1 & 333 \\
\hline & (Sig. (2-tailed & 000 & 000 & 000 & 000 \\
\hline & $\mathrm{N}$ & 200 & 200 & 200 & 200 \\
\hline \multirow{3}{*}{$\begin{array}{l}\text { Uniqueness } \\
\text { Of Image }\end{array}$} & Pearson Correlation & 838 & ${ }^{* *} 219$, & ${ }^{* * 5} 511$, & 1 \\
\hline & (Sig. (2-tailed & 000 & 000 & 000 & 000 \\
\hline & $\mathrm{N}$ & 200 & 200 & 200 & 200 \\
\hline
\end{tabular}

(Sumber: Olahan Peneliti Menggunakan SPSS 20, 2015)

Berdasarkan tabel tersebut dapat kita ketahui hubungan variabel renaming terhadap variabel corporate image dengan sub variabel strength of image, favorability of image, dan uniqueness of image. Hasil dari nilai $r$ tersebut akan ditafsirkan dengan koefisien korelasi signifikansi dan interval kekuatan. Menurut Sugiyono (2002: 40) jika nilai Sig. (2-tailed) $<0,05$ maka hubungan yang terdapat pada $r$ dianggap signifikan. Hasil korelasi pearson tersebut dapat dijelaskan dengan penafsiran berikut:

a). Nilai $\mathrm{r}$ pada renaming terhadap strength of image adalah sebesar 0,451 ( $\mathrm{r}=0,451)$, karena hasilnya tidak sama dengan 0 , maka dapat dikatakan ada hubungan antara kedua variabel. Kemudian nilai $\mathrm{r}$ tersebut dalam bentuk positif, maka arah hubungannya dinyatakan berhubungan secara positif. Sesuai dengan interval koefisien korelasi maka tingkat hubungannya adalah cukup kuat. Dengan tingkat signifikansi koefisien korelasi 0.000, maka hubungan renaming dengan strength of image adalah signifikan.

b). Nilai r pada renaming terhadap favorability of image adalah sebesar 0,513 ( $\mathrm{r}=0,513)$, karena hasilnya tidak sama dengan 0 , maka dapat dikatakan ada hubungan antara kedua variabel. Kemudian nilai $r$ tersebut dalam bentuk positif, maka arah hubungannya dinyatakan berhubungan secara positif. Sesuai dengan interval koefisien korelasi maka tingkat hubungannya adalah cukup kuat. Dengan tingkat signifikansi koefisien korelasi 0.000 , hal ini berarti hubungan renaming dengan favorability of image adalah signifikan.

c). Nilai r pada renaming terhadap uniqueness of image adalah sebesar $0,838(\mathrm{r}=0,838)$, karena hasilnya tidak sama dengan 0 , maka dapat dikatakan ada hubungan antara kedua variabel. Kemudian nilai $r$ tersebut dalam bentuk positif, maka arah hubungannya dinyatakan berhubungan secara positif. Sesuai dengan interval koefisien korelasi maka tingkat hubungannya adalah sangat kuat. Dengan tingkat signifikansi koefisien korelasi 0.000 , hal ini berarti hubungan renaming dengan uniqueness of image adalah signifikan.

Koefisien determinasi digunakan untuk menafsirkan skor korelasi pearson (r). Koefisien determinasi $\left(r^{2}\right)$ menunjukkan besarnya sumbangan efektif variabel besab terhadap variabel terikat. Berdasarkan hasil nilai $r$ yang diperoleh diatas, maka dapat diketahui koefisien determinasi adalah sebagai berikut:

a). Nilai $\mathrm{r}$ renaming terhadap strength of image adalah $0,451 \times 0,451=0,2034$, kemudian dikalikan $100 \%$ maka $0,2034 \times 100 \%=$ $20,34 \%$. Hal ini berarti bahwa renaming yang dilakukan Telkom University memberikan sumbangan efektif sebesar 20,34\% terhadap strength of image Telkom University. Kondisi ini mengindikasi bahwa strength of image Telkom University dipengaruhi oleh renaming yang dilakukan 
Telkom University sebesar 20,34\%.

b). Nilai $\mathrm{r}$ renaming terhadap strength of image adalah $0,513 \times 0,513=0,26319$, kemudian dikalikan $100 \%$ maka 0,26319 $\mathrm{x} 100 \%=26,31 \%$. Hal ini berarti bahwa renaming yang dilakukan Telkom University memberikan sumbangan efektif sebesar 26,31\% terhadap favorability of image Telkom University. Kondisi ini mengindikasi bahwa favorability of image Telkom University dipengaruhi oleh renaming yang dilakukan Telkom University sebesar $26,31 \%$.

c). Nilai $\mathrm{r}$ renaming terhadap strength of image adalah $0,838 \times 0,838=0,7022$, kemudian dikalikan $100 \%$ maka 0,7022 x $100 \%=70,22 \%$. Hal ini berarti bahwa renaming yang dilakukan Telkom University memberikan sumbangan efektif sebesar 70,22\% terhadap uniqueness of image Telkom University. Kondisi ini mengindikasi bahwa uniqueness of image Telkom University dipengaruhi oleh renaming yang dilakukan Telkom University sebesar 70,22\%.

Kemudian dalam penelitian ini juga menggunakan analisis regresi, yang digunakan untuk meramalkan bagaimana keadaan (naik turunnya) variabel dependen, bila dua atau lebih variabel independen sebagai faktor prediktor dinaik turunkan nilainya (Sugiyono, 2010: 275).

Pada penelitian ini, analisis regresi berganda dimaksudkan untuk mengetahui adanya pengaruh renaming dengan indikator penerimaan $\left(\mathrm{X}_{1}\right)$, ketersediaan $\left(\mathrm{X}_{2}\right)$, keunikan $\left(\mathrm{X}_{3}\right)$, kredibilitas $\left(\mathrm{X}_{4}\right)$ dan kesesuaian $\left(\mathrm{X}_{5}\right)$ terhadap corporate image Telkom University di mata masyarakat Kota Bandung. Tujuannya untuk meramalkan atau memperkirakan nilai variabel dependen dalam hubungan sebabakibat terhadap nilai variabel lain.

Dengan menggunakan bantuan aplikasi program SPSS 20, didapat output hasil perhitungan regresi linier berganda sebagai berikut:
Pengaruh Perubahan Nama Terhadap Citra Pada Telkom University

Tabel Hasil Regresi Linier

Berganda

\begin{tabular}{|l|c|c|c|c|c|}
\hline \multirow{2}{*}{ Model } & \multicolumn{2}{|c|}{$\begin{array}{c}\text { Un- } \\
\text { standardized } \\
\text { Coefficients }\end{array}$} & $\begin{array}{c}\text { Standardized } \\
\text { Coefficients }\end{array}$ & \multirow{2}{*}{$\mathrm{t}$} & \multirow{2}{*}{ Sig } \\
\cline { 2 - 4 } & $\mathrm{B}$ & $\begin{array}{c}\text { Std. } \\
\text { Error }\end{array}$ & Beta & & \\
\hline Constant))1 & 905. & 328. & 154. & 1.620 & 000. \\
Penerimaan & 368. & 117. & 204. & 2.796 & 006. \\
Ketersediaan & 172. & 106. & 418. & 2.461 & 007. \\
Keunikan & 477. & 171. & 252. & 5.317 & 009. \\
Kredibilitas & 174. & 033. & 311. & 5.402 & 000. \\
Kesesuaian & 225. & 042. & & & \\
\hline
\end{tabular}

(Sumber: Olahan Peneliti berdasarkan SPSS 20)

Berdasarkan Tabel tersebut, maka dapat dibuat persamaan regresi linier berganda sebagai berikut:

$0,368 X_{3}+0,174 X_{4}+0,225 X_{5}{ }^{1}+0,172 X_{2}$

Dari persamaan regresi linier diatas, dapat dijelaskan sebagai berikut:

a). Nilai konstanta a memiliki arti bahwa ketika variabel renaming bernilai nol atau corporate image tidak dipengaruhi oleh indikator penerimaan, maka variabel corporate image bernilai 0,905 atau 90,5\% .

b). Koefisien regresi indikator penerimaan $\left(\mathrm{X}_{1}\right)$ sebesar 0,368. Artinya jika indikator penerimaan mengalami kenaikan satusatuan, maka variabel corporate image (Y) akan mengalami peningkatan sebesar 0,368 satuan atau $36,8 \%$.

c). Koefisien regresi indikator ketersediaan $\left(\mathrm{X}_{2}\right)$ sebesar 0,172 . Artinya jika indikator ketersediaan mengalami kenaikan satusatuan, maka variabel corporate image (Y) akan mengalami peningkatan sebesar 0,172 satuan atau $17,2 \%$.

d). Koefisien regresi indikator keunikan $\left(\mathrm{X}_{3}\right)$ sebesar 0,477. Artinya jika indikator keunikan mengalami kenaikan satusatuan, maka variabel corporate image (Y) akan mengalami peningkatan sebesar 0,477 satuan atau $47,7 \%$.

e). Koefisien regresi indikator kredibilitas $\left(\mathrm{X}_{4}\right)$ sebesar 0,174. Artinya jika indikator kredibilitas mengalami kenaikan satu- 
satuan, maka variabel corporate image

(Y) akan mengalami peningkatan sebesar 0,174 satuan atau $17,4 \%$.

f). Koefisien regresi indikator kesesuaian $\left(\mathrm{X}_{5}\right)$ sebesar 0,225. Artinya jika indikator kesesuaian mengalami kenaikan satusatuan, maka variabel corporate image (Y) akan mengalami peningkatan sebesar 0,225 satuan atau $22,5 \%$.

Berdasarkan hasil analisis regresi tersebut, dapat diketahui bahwa indikator keunikan pada variabel renaming memiliki pengaruh terbesar yaitu $44,7 \%$ terhadap variabel corporate image.

Untuk mengetahui seberapa besar pengaruh yang diberikan variabel $\mathrm{X}$ (renaming) terhadap variabel Y (corporate image), maka digunakan analisis koefisien determinasi, dan berikut hasilnya:

Tabel Koefisien Determinasi

\begin{tabular}{|c|c|c|c|c|}
\hline Model & $\mathrm{R}$ & $\begin{array}{c}\mathrm{R} \\
\text { Square }\end{array}$ & $\begin{array}{c}\text { Adjusted } \\
\mathrm{R} \\
\text { Square }\end{array}$ & $\begin{array}{c}\text { Std. Error of } \\
\text { the Estimate }\end{array}$ \\
\hline 1 & $582^{\mathrm{a}} \cdot$ & 339. & 333. & 40330. \\
\hline
\end{tabular}

a. Predictors: (Constant), X5, X4, X3, X2, $\mathrm{X} 1$

b. Dependent Variable: Y

(Sumber: Hasil Olahan Peneliti dari SPSS 20)

$$
\begin{aligned}
\mathrm{KD} & =\mathrm{r}^{2} \times 100 \% \\
\mathrm{KD} & =(0,582)^{2} \times 100 \% \\
& =33,87 \%
\end{aligned}
$$

Hasil analisis diatas, menunjukkan bahwa variabel renaming yang terdiri atas indikator penerimaan, ketersediaan, keunikan, kredibilitas dan kesesuaian memiliki pengaruh terhadap variabel corporate image yaitu sebesar $33,87 \%$, sedangkan sisanya sebesar $66,13 \%$ dipengaruhi oleh faktor lain yang tidak diamati dalam penelitian ini.

\section{Pembahasan}

Berdasarkan analisa data penelitian, dapat disampaikan kesimpulan hasil penelitian sebagai berikut:

a. Hasil yang diperoleh dari pengujian hipotesis menunjukkan bahwa terdapat hubungan yang signifikan antara renaming STT Telkom menjadi Telkom University terhadap strength of image Telkom University pada masyarakat Kota Bandung. Sebagaimana yang ditunjukkan oleh koefisien korelasi sebesar 0,451 dengan taraf signifikansi korelasi 0,000. Skor korelasi tersebut menunjukkan bahwa terdapat hubungan positif dan signifikan antara renaming STT Telkom menjadi Telkom University terhadap strength of image Telkom University.

Keadaan ini berarti bahwa semakin baik renaming yang dilakukan Telkom University maka semakin tinggi strength of image Telkom University. Sebaliknya, jika renaming yang dilakukan Telkom University dipersepsikan negatif oleh masyarakat, maka strength of image Telkom University akan semakin menurun. Hasil analisis menunjukkan, hipotesis yang diajukan peneliti, yang menyatakan renaming berpengaruh terhadap strength of image Telkom University dapat diterima.

Keller (2008: 56) menyatakan bahwa strength of image tergantung dari banyaknya jumlah atau kuantitas dan kualitas informasi yang diterima oleh konsumen. Semakin dalam konsumen menerima informasi merek, semakin kuat asosiasi merek yang dimilikinya. Dua faktor yang mempengaruhi strengthness of image yaitu hubungan personal dari informasi tersebut dan konsistensi informasi tersebut sepanjang waktu.

Identitas perusahaan dapat ditunjukkan dalam beberapa bentuk seperti cara berkomunikasi, perilaku, dan simbol (Riel \& Fombrun, 2007). Hal ini berarti, identitas perusahaan diwakili oleh beberapa atribut yang berkaitan dengan sebuah perusahaan. Ardianto (2011: 60) menjelaskan bahwa sebuah identitas perusahaan memiliki empat elemen dasar, yakni: (1) nama organisasi atau perusahaan, (2) bentuk logo, (3) 
bentuk huruf, dan (4) jenis warna. Kemudian dari elemen tersebut akan membentuk citra perusahaan itu sendiri.

Sesuai dengan interval koefisien korelasi $\quad(\mathrm{r}=0,451) \quad$ maka tingkat hubungannya adalah cukup kuat. Hal ini berarti masyarakat Kota Bandung sudah cukup kuat menerima informasi atribut nama Telkom University sehingga akan menciptakan strength of image Telkom University yang cukup kuat. Semakin masyarakat menerima informasi merek secara konsisten dan terus menerus, maka semakin meningkat juga strength of image yang diciptakan.

b. Hasil yang diperoleh dari pengujian hipotesis menunjukkan bahwa terdapat hubungan yang signifikan antara renaming STT Telkom menjadi Telkom University terhadap favorability of image Telkom University pada masyarakat Kota Bandung. Sebagaimana yang ditunjukkan oleh koefisien korelasi sebesar 0,513 dengan taraf signifikansi korelasi 0,000. Skor korelasi tersebut menunjukkan bahwa terdapat hubungan positif dan signifikan antara renaming STT Telkom menjadi Telkom University terhadap favorability of image Telkom University.

Keadaan ini berarti bahwa semakin baik renaming yang dilakukan Telkom University maka semakin tinggi favorability of image Telkom University. Sebaliknya, jika renaming yang dilakukan Telkom University dipersepsikan negatif oleh masyarakat, maka favorability of image Telkom University akan semakin menurun. Hasil analisis menunjukkan, hipotesis yang diajukan peneliti, yang menyatakan renaming berpengaruh terhadap favorability of image Telkom University dapat diterima.

Keller (2008: 56) menyatakan bahwa favorability of image terbentuk oleh program pemasaran yang berjalan efektif mengantarkan produk-produknya menjadi produk yang disukai oleh konsumen. Kesenangan konsumen terhadap merek tersebut berdasarkan keunggulan merek.

Gronroos (Sutisna, 2002: 29) menjelaskan bahwa citra menceritakan harapan bersama dengan kampanye pemasaran eksternal, seperti periklanan, penjualan pribadi dan komunikasi dari mulut ke mulut. Dengan pemasaran yang ada, konsumen dapat mengetahui informasi produk dan keunggulan sehingga produk tersebut dapat menjadi populer dan disukai konsumen.

Shimp (2003: 301) juga menjelaskan bahwa corporate image yang posittif dapat meningkatkan dikenalnya nama perusahaan, membangun itikad baik bagi perusahaan serta produknya, atau mengidenfitikasikan dirinya sendiri dengan beberapa aktivitas yang bisa diterima secara sosial dan bermakna.

Sesuai dengan interval koefisien korelasi $(\mathrm{r}=0,513)$ maka tingkat hubungannya adalah cukup kuat. Hal ini berarti masyarakat Kota Bandung sudah cukup kuat mengetahui keunggulan dan menyukai Telkom University sehingga akan menciptakan favorability of image Telkom University yang cukup kuat. Semakin masyarakat menyukai merek dari keunggulan merek tersebut, maka semakin meningkat juga favorability of image yang diciptakan.

c. Hasil yang diperoleh dari pengujian hipotesis menunjukkan bahwa terdapat hubungan yang signifikan antara renaming STT Telkom menjadi Telkom University terhadap uniqueness of image Telkom University pada masyarakat Kota Bandung. Sebagaimana yang ditunjukkan oleh koefisien korelasi sebesar 0,838 dengan taraf signifikansi korelasi 0,000. Skor korelasi tersebut menunjukkan bahwa terdapat hubungan positif dan signifikan antara renaming STT Telkom menjadi Telkom University terhadap uniqueness of image Telkom University.

Keadaan ini berarti bahwa semakin baik renaming yang dilakukan Telkom 
University maka semakin tinggi uniqueness of image Telkom University. Sebaliknya, jika renaming yang dilakukan Telkom University dipersepsikan negatif oleh masyarakat, maka uniqueness of image Telkom University akan semakin menurun. Hasil analisis menunjukkan, hipotesis yang diajukan peneliti, yang menyatakan renaming berpengaruh terhadap uniqueness of image Telkom University dapat diterima.

Keller (2008: 56) menyatakan bahwa dengan adanya asosiasi unik dari suatu merek, akan tercipta keuntungan kompetitif dan alasan-alasan mengapa konsumen sebaiknya membeli brand tersebut. Konsep unik dari produk yang membuat suatu merek menjadi lain dari pada yang lain.

Selaras dengan pernyataan Keller, Susanto dan Wijanarko (2004: 2) juga menyebutkan bahwa citra perusahaan adalah hasil dari sebuah proses dimana konsumen telah membandingkan berbagai atribut yang dimiliki perusahaan. Perusahaan dengan atribut yang unik tentu akan menarik perhatian konsumen. Maka dari itu konsep unik dirancang agar konsumen "tidak ada alasan untuk tidak" memilih merek tersebut.

Selain itu, suatu identitas yang dimiliki perusahaan memang diharuskan memiliki keunikan tersendiri. Seperti yang dijelaskan oleh M. Linggar Anggoro (2000: 280) bahwa identitas perusahaan adalah suatu cara atau suatu hal yang memungkinkan suatu perusahaan dikenal dan dibedakan dari perusahaan-perusahaan lainnya. Maka dari itu keunikan suatu brand atau perusahaan merupakan hal penting yang harus dimiliki perusahaan.

Sesuai dengan interval koefisien korelasi $(r=0,838)$ maka tingkat hubungannya adalah sangat kuat. Hal ini berarti masyarakat Kota Bandung menganggap nama Telkom University tersebut memiliki keunikan yang sangat kuat, sehingga akan menciptakan uniqueness of image Telkom University yang cukup kuat. Se- makin masyarakat mempersepsikan unik suatu merek, maka semakin meningkat juga uniqueness of image yang diciptakan.

Berdasarkan ketiga hasil analisa hipotesis minor tersebut, maka hipotesis mayor dalam penelitian ini yang menyatakan terdapat pengaruh renaming Telkom University terhadap corporate image Telkom University pada masyarakat Kota Bandung dapat diterima.

Knapp (2004: 122) menjelaskan bahwa nama yang efektif mendorong proses pembangunan nilai atau memperkuat nilai dari merek. Nama yang efektif adalah tanda pertama yang dapat digunakan oleh sebuah merek untuk menciptakan kesan khusus dan positif.

Nama merek bertujuan untuk mengkomunikasikan dan memposisikan citra merek. Nama merek sangat penting, bahkan sebuah nama adalah "saklar otak besar yang mengaktifkan sebuah citra dalam pikiran pemirsa" (Shimp, 2003: 299).

Berdasarkan hasil analisis regresi menunjukkan bahwa variabel renaming memiliki pengaruh terhadap variabel corporate image sebesar 33,87\%. Dengan indikator keunikan dalam variabel renaming memiliki pengaruh secara parsial yang paling besar yaitu $47,7 \%$, sesuai dengan tingkat interpretasi nilai $r$, maka nilai tersebut termasuk dalam kategori cukup kuat.

Keadaan ini berarti, semakin baik nama Telkom University maka akan semakin tinggi nilai positif atau citra Telkom University. Sebaliknya, jika nama Telkom University dipersepsikan negatif oleh masyarakat, maka citra Telkom University juga akan semakin menurun.

\section{Kesimpulan}

Berdasarkan hasil penelitian pada bab sebelumnya serta pembahasan yang disertai dengan teori - teori yang mendukung, maka diperoleh kesimpulan sebagai berikut : 
Felesia Ekafaya Kirianawati, Roro Retno Wulan, Kharisma Nasionalita

Penelitian ini membuktikan bahwa renaming STT Telkom menjadi Telkom University berpengaruh terhadap strenght of image Telkom University. Semakin positif nama Telkom University di mata masyarakat, maka akan diikuti dengan meningkatnya strength of image Telkom University. Sebaliknya, jika nama Telkom University dipersepsikan negatif oleh masyarakat, maka strength of image Telkom University juga akan semakin menurun.

Penelitian ini membuktikan bahwa renaming STT Telkom menjadi Telkom University berpengaruh terhadap favorability of image Telkom University. Semakin positif nama Telkom University di mata masyarakat, maka akan diikuti dengan meningkatnya favorability of image Telkom University. Sebaliknya, jika nama Telkom University dipersepsikan negatif oleh masyarakat, maka favorability of image Telkom University juga akan semakin menurun.

Penelitian ini membuktikan bahwa renaming STT Telkom menjadi Telkom University berpengaruh terhadap uniqueness of image Telkom University. Semakin positif nama Telkom University di mata masyarakat, maka akan diikuti dengan meningkatnya uniqueness of image Telkom University. Sebaliknya, jika nama Telkom University dipersepsikan negatif oleh masyarakat, maka uniqueness of image Telkom University juga akan semakin menurun.

Berdasarkan ketiga hasil analisa penelitian tersebut, maka dapat ditarik kesimpulan bahwa secara garis besar terdapat pengaruh renaming Telkom University terhadap corporate image Telkom University pada masyarakat Kota Bandung. Jadi semakin baik nama Telkom University maka akan semakin tinggi citra Telkom University. Sebaliknya, jika nama Telkom University dipersepsikan negatif oleh masyarakat, maka citra Telkom University juga akan semakin menurun. Berdasarkan hasil analisis regresi menunjukkan bahwa variabel renaming memiliki pengaruh terhadap variabel corporate image sebesar $33,87 \%$. Sedangkan sisanya sebesar $66,13 \%$
Pengaruh Perubahan Nama Terhadap Citra Pada Telkom University

dipengaruhi oleh faktor lain yang tidak diamati dalam penelitian ini. Faktor lain tersebut dapat diasumsikan adalah ketiga elemen rebranding yaitu repositioning, redesign dan relaunch. Jika dilihat dari besarnya sisa persentase yaitu 66,13\%, masing-masing elemen tersebut memiliki nilai sebesar 22\%. Maka dari itu dapat disimpulkan bahwa elemen renaming yang memiliki pengaruh lebih besar dibandingkan dengan elemen lain dalam rebranding. Dengan indikator keunikan dalam variabel renaming memiliki pengaruh secara parsial yang paling besar yaitu $47,7 \%$, sesuai dengan tingkat interpretasi nilai $r$, maka nilai tersebut termasuk dalam kategori cukup kuat.

\section{Daftar Pustaka}

Alifahmi, Hifni. (2012). Marketing Communication Orchestra: Harmonisasi Iklan, Promosi, Dan Marketing Public Relation. Cet ke-3. Bandung: Examedia Publishing.

Anggoro, M Linggar. (2000). Teori \& Profesi Kehumasan Serta Aplikasinya Di Indonesia. Jakarta: PT Bumi Aksara.

Ardianto, Elvinaro. (2011). Handbook Of Public Relation: Pengantar Komprehensif. Bandung: Simbiosa Rekatama Media.

Cutlip., Scott M., Center Allen \& Broom Glen M. (2009). Effective Public Relations. USA: Prentice Hall.

Jefkins, Frank. (2003). Public Relations. Jakarta: Erlangga.

Kapferer, J., N. (1997). Strategic Brand Management: New Approaches to Creating and Evaluating Brand Equity. New York: The Free Press.

Keller, Kevin., Tony Aperia., Mats Georgson. (2008). Strategic Brand Management: A European Perspective. USA: Prentice Hall.

Knapp, Duane. (2004). The Complete Ideal's Guide Brand Management. Jakarta: Prenada Media. 
Felesia Ekafaya Kirianawati, Roro Retno

Wulan, Kharisma Nasionalita

Kotler, Philip \& Kevin L. Keller. (2009). Marketing Management $13^{\text {th }}$ Edition. New Jersey: Prentince Hall International, Inc..

Muzellec, Laurent., Mary Lambkin and Manus Doogan. (2003). "Corporate Rebranding: An Exploratory Review”. Irish Marketing Review, Vol 16, No 2, pp 31-40.

Muzellec, Laurent., Mary Lambkin and Manus Doogan. (2006). Corporate Rebranding Destroying, Transfering or Creating Brand Equity. Journal of Marketing. Vol 40 No 7/8 pp 803-824.

Rangkuti, Freddy. (2008). The Power of Brands: Teknik Mengelola Brand Equity dan Strategi Pengembangan Merek. Jakarta: Gramedia.

Riduwan \& Akdon. (2009). Rumus dan Data Dalam Analisis Statistika. Bandung: Alfabeta.

Riel, Van., Cees., Charles J Fombrun. (2007). Essentials of Corporate Communications: Implementing Practice for Effective Reputation Management. USA: Routledge - Taylor \& Francis eLibrary.
Pengaruh Perubahan Nama Terhadap Citra Pada Telkom University

Ruslan, Rosady. (2002). Kiat dan Strategi Public Relation. Jakarta: Grafindo Persada.

Shimp, Terence A. (2003). Periklanan Dan Promosi. Edisi kelima. Jakarta: Erlangga.

Smith, Paul R. (1995). Marketing Communication an Integrated Approach $2^{\text {nd }}$ Edition. London: Kogan Page.

Siregar, Syofian. (2013). Metode Penelitian Kuantitatif. Edisi Pertama. Jakarta: Kencana Prenada Media.

Susanto, A.B \& Wijanarko Himawan. (2004). Power Branding: Membangun Brand Yang Legendaris. Jakarta: Mizan.

Sutisna. (2002). Perilaku Konsumen \& Komunikasi Pemasaran. Cetakan Kedua. Bandung: PT Remaja Rosdakarya. 